\title{
Sto lat metody projektów w Polsce
}

\begin{abstract}
A Hundred Years of the Project Method in Poland
The text presents the development of the project method in Polish education throughout the last century. The project method was introduced into Poland after regaining independence, and it was implemented during the inter-war period (1918-1939) in some schools, both in urban and rural environments. Nevertheless, the method was at that time treated as a pedagogical novelty and experiment, rather than a natural part of school life. After 1945, education, like other aspects of socio-political life, was influenced by the communist propaganda, and the project method, supporting autonomy, democracy and empowerment, was not promoted as a valuable educational approach. After 1989, when progressive trends appeared in Polish schools, the project method gained some popularity but it was not until 2008 when it was granted national and formal recognition. Then, the new core curriculum was developed, and the project method became an obligatory part of school reality. The revival of the project method was connected with the alarming findings concerning social capital in Poland. In this situation, making students cooperate within projects seemed a remedy for the decreasing social capital. As the author points out, formal introduction of the method does not necessarily mean its effective accomplishment, which should be accompanied by spontaneity and authentic engagement. What is more, as the author shows, after decades of the absence of this method in Poland, and the lack of the relevant socio-cultural background, teachers might find it difficult to implement a project so as to contribute to the increase of social capital. All these areas need further investigation. Nevertheless, the author hopes that the text will contribute to better understanding of contemporary challenges and opportunities related to the implementation of the idea of projects in Polish education.
\end{abstract}

Keywords: project method, Poland, education 


\section{Wprowadzenie}

Metoda projektów należy dziś do znanego uczniom i nauczycielom repertuaru aktywizujących sposobów nauczania, stosowanego powszechnie na różnych szczeblach szkolnej edukacji. Kwestia interpretacji samego pojęcia metoda projektów i praktyczne sposoby jej realizacji stanowią z pewnością interesujący obszar pedagogicznych dociekań, natomiast celem artykułu jest analiza rozwoju popularności tej metody na przestrzeni wieku. W owym rozwoju, okresy żywego zainteresowania nowatorskim sposobem pracy były przeplatane dekadami zapomnienia, po których nastąpił czas ponownego docenienia omawianej metody $\mathrm{w}$ edukacyjnej rzeczywistości. Tekst powstał $\mathrm{w}$ oparciu o analizę przedwojennych i współczesnych czasopism i publikacji pedagogicznych, w których poruszano temat będący przedmiotem opracowania. Mam nadzieję, że takie spojrzenie wstecz może przyczynić się do lepszego zrozumienia współczesnych wyzwań, problemów i możliwości, które łączą się z realizacją projektów w polskiej oświacie.

\section{Metoda projektów w Polsce w latach 1918-1939}

Jak zauważa Mirosław Szymański, założenia metody dotarły do Polski głównie za sprawą pracy Johna Alforda Stevensona pt. The Project Method ${ }^{l}$, przetłumaczonej na język polski 10 lat po jej publikacji w Stanach Zjednoczonych. W przedwojennych czasopismach pedagogicznych znajdują się omówienia tej metody (zwanej metoda zamierzeń) z powoływaniem się właśnie na tę publikację, choć była ona dziełem raczej wtór$n^{2}$. Jeden $\mathrm{z}$ pierwszych artykułów opublikowanych w Polsce dotyczący metody projektów pochodzi z roku 1925 z czasopisma „Praca Szkolna” i bazuje właśnie na tekście J. A. Stevensona ${ }^{3}$. Także w oparciu o tekst wspomnianego amerykańskiego autora w 1927 r. na łamach „Ruchu Pedagogicznego” opisywano metodę projektów, zwracając uwagę na takie jej cechy, jak powiązanie myślenia logicznego z działaniem mającym odniesienie do realnego życia, odmienną od tradycyjnej rolą nauczyciela i aktywizujący przebieg zajęć c $^{4}$ Ponieważ przed wojną opracowanie J. A. Stevensona było jedyną książką przetłumaczoną na język polski dotyczącą omawianej metody, to ją właśnie pedagodzy powszechnie traktowali jako źródło wiedzy ${ }^{5}$. Autorką, która w swoim opracowaniu odnosiła się do szerszej perspektywy, posiłkując się m.in. tekstami Johna Deweya i Wil-

1 J. A. Stevenson, Metoda projektów w nauczaniu, Lwów-Warszawa 1930.

2 M. Szymański, O metodzie projektów. Z historii, teorii i praktyki pewnej metody kształcenia, Warszawa 2000, s. 44-46.

${ }^{3}$ F. Bereźnicki, Hasła „Nowej szkoly” w dydaktyce drugiej Rzeczpospolitej, Toruń 1998, s. 129.

${ }^{4}$ H.K. (a), Metoda , projektów”, , „Ruch Pedagogiczny” R. XIV, 1927, nr 5, s. 147-151; H.K. (b), Metoda „projektów”, „Ruch Pedagogiczny” R. XIV, 1927, nr 4, s. 118-121.

${ }^{5}$ H. Rowid, Henryk Szkoła twórcza, Kraków 1931, s. 325-340; W. Dzierzbicka, S. Dobrowolski, Eksperymenty pedagogiczne $w$ Polsce $w$ latach 1900-1939, Wrocław 1963, s. 303; Bereźnicki, op. cit., s. 130-135; Szymański, op. cit., s. 45. 
liama Kilpatricka była Zofia Bastgenówna. Analizując zasady metody projektów, autorka wskazywała takie jej zalety, jak dowartościowanie dziecka i jego zainteresowań, kształcenie samodzielności i umiejętności pracy. Jednocześnie według Z. Bastgenówny metoda projektów obarczona była nadmiernym utylitaryzmem i łączyła się z powierzchownością działań edukacyjnych. Ponadto, autorka podzielała opinię, że metoda jest dobra, ale przejściowa forma wychowania, ułatwiająca dopływ nowych pomystów, świeżych sił i coraz to innych przedsięwzięć, lecz cierpiaca zarazem na nagte skoki i gwattowne odchylenia od pewnego zakresu nauki ${ }^{6}$.

W wymiarze praktycznym, metoda projektów stosowana przez nielicznych w Polsce pedagogów wydawała się atrakcyjna ze względu na jej aspekt psychologiczny (uwzględnianie psychicznego rozwoju dzieci) i społeczny (użyteczność wytworów pracy, wdrażanie do pracy zbiorowej, współdziałania i współodpowiedzialności). Ponadto, wskazywano na elastyczność metody, czyli możliwość jej stosowania w różnych grupach wiekowych i warunkach szkolnych. Jednocześnie, jak zauważają W. Dzierzbicka i S. Dobrowolski, polscy pedagodzy starali się, aby w naszym kraju stosowanie metody projektów nie byto biernym naśladownictwem amerykańskich wzorów, ale twórczym rozwiąywaniem zagadnienia uznanego za ważne $[. .]^{7}$. Szkoły przedwojenne, w których stosowano omawianą metodę w sposób świadomy i planowy, to m.in. w Szkoła Ćwiczeń przy Państwowym Seminarium Żeńskim im. E. Orzeszkowej w Warszawie (1926-1939), Szkoła Powszechna w Mosinie (1932-1936) oraz Szkoła Powszechna w Hołobach koło Kowla (19281939) ${ }^{8}$. Ostatnia z wymienionych placówek jest przykładem kompleksowej, wieloletniej realizacji metody projektów, dzięki której przekształcono nie tylko szkołę, ale odciśnięto piętno na lokalnej społeczności. W Hołobach dyrekcja szkoły wraz z zespołem pedagogów, uczniami i z biegiem czasu także rodzicami, prowadziła systematyczne prace związane z jednej strony z zagospodarowywaniem terenu wokół szkoły i szkolnego ogrodu, a $\mathrm{z}$ drugiej z samodzielnym wytwarzaniem pomocy dydaktycznych dla uczniów. Wszelkie wykonywane prace miały wymiar przedmiotowy, np. prace ogrodnicze stanowiły podbudowę lekcji biologii i matematyki, zagospodarowywanie terenu wokół szkoły łączyło się ze wspólnym planowaniem prac, obliczaniem kosztów, wyborem materiałów, pisaniem listów $\mathrm{z}$ prośbą o pomoc $\mathrm{w}$ realizacji przedsięwzięcia, by następnie znaleźć odbicie w uczniowskich pracach pisemnych i odpowiednio dobieranych tekstach literackich. Co ważne, praca szkoły zaczęła oddziaływać na lokalne środowisko, aktywizując rodziców i wpływając na ich postawy prospołeczne9. Jako placówkę, gdzie najdłużej (1926-1939) realizowano w Polsce metodę projektów wymienia się Szkołę Ćwiczeń przy Państwowym Seminarium Żeńskim im. E. Orzeszkowej w Warszawie. Planując pracę, czerpano z pracy J.A. Stevensona, nawet zanim została ona przetłumaczona na język polski. Metoda projektów stała się formą pracy głównie w klasach najmłodszych (I i II), następnie była kontynuowana jako metoda dodatkowa aż do klasy VI. Pierwsze przedsię-

\footnotetext{
6 Z. Bastgenówna, Metoda projektów, „Ruch Pedagogiczny” R. XVII, 1930, nr 6, s. 268-274.

${ }^{7}$ W. Dzierzbicka, S. Dobrowolski, op. cit., s. 306.

8 M. Szymański, op. cit., 47.

9 W. Dzierzbicka, S. Dobrowolski, op. cit., s. 313-314.
} 
wzięcia, zwane „zamierzeniami” przeprowadzane z dziećmi najmłodszymi dotyczyły nauki rachunków, którą łączono z pracami ogrodowymi, rysunkami i pracami ręcznymi i w rezultacie $w$ sposób zupetnie naturalny nauczanie przedmiotowe $w$ tych klasach zostało zastapione przez nauczanie mające za punkt wyjścia najbliższe środowisko dziecka $i$ jego przeżycia $w$ tym środowisku, przy uwzględnieniu $w$ najszerszej mierze własnej aktywności uczniów ${ }^{10}$. Poza wymienionymi szkołami, elementy metody projektów były realizowane także w kilku innych placówkach (Turkowicze, Mosina, Warszawa, Wilno), przybierając formę działań raczej jednorazowych niż planowych i systematycznych. Nie było przy tym szkoły, w której ta metoda byłaby wyłączną metodą pracy, nawet w przypadku omawianej szkoły warszawskiej. Analiza realizacji projektów w szkole w Warszawie i Hołobach pokazuje, że w drugiej z wymienionych placówek projekty miały mieć przede wszystkim wartość użytkową, co wynikało z podstawowego założenia, aby przez pracę w szkole pozytywnie zmieniać środowisko. Jeśli chodzi o szkołę warszawską, to celem był wszechstronny rozwój osobowości dzieci, bez szkolnego przymusu, ale przez organizację pracy szkolnej i osobowość nauczyciela - towarzysza i doradcy ${ }^{11}$.

\section{Lata powojenne}

Po roku 1945, choć polska oświata ulegała całościowym przeobrażeniom, owe zmiany nie miały na celu wychowania w duchu aktywnej, uczestniczącej demokracji, autonomii czy współdziałania, które stanowią rdzeń metody projektów. Oficjalnie zadekretowane wówczas wychowanie „nowego człowieka” oznaczało ideał wychowawczy oparty na posłuszeństwie i zależności, przy zaangażowaniu dopuszczalnym w ściśle ustalonych ramach wyznaczanych przez komunistyczną ideologię. Chociaż przyznawano tej metodzie poczesne miejsce w historii myśli pedagogicznej podkreślając cechy, dzięki którym na nie zasługuje (nacisk na aktywność dziecka i zbliżenie szkoły do życia), jednocześnie przedstawiano ją jako relikt przeszłości, pomysł realizowany w latach 20. i 30. w Stanach Zjednoczonych, znany przed wojną w Polsce, ale obcy „psychice ówczesnego społeczeństwa polskiego", który ostatecznie nie przyjął się w praktyce edukacyjnej ${ }^{12}$. Z kolei Józef Pieter wskazywał że dotychczas lansowane metody szkoły aktywnej, w szczególności metoda daltońska, projektów, itp. okazały się niezbyt praktyczne i kosztowne ${ }^{13}$. Metoda projektów była w niewielkim stopniu wspominana w popularnych podręcznikach dla studentów kierunków pedagogicznych ${ }^{14}$, a autorzy tych opracowań bazowali jedynie na pracy

\footnotetext{
10 Ibidem, s. 321.

11 Ibidem, s. 331-332.

12 A. Molak, Metoda projektów, w: Szkoły eksperymentalne w świecie 1900-1975, red. W. Okoń, Warszawa 1977 , s. 56- 70.

13 J. Pieter, Johna Dewey’a myśli przewodnie o wychowaniu, „Chowanna” R. XIII, 1958, nr 5/6, s. 273.

${ }^{14}$ S. Wołoszyn, Dzieje wychowania i myśli pedagogicznej w zarysie, Warszawa 1964, s. 419; K. Sośnicki, Dydaktyka ogólna, Wrocław1959, s. 206-208; B. Nawroczyński, Dzieła wybrane. Zasady nauczania, tom II, Warszawa: WSiP, 1987, s. 316-320.
} 
J. A. Stevensona ${ }^{15}$. Niektórzy z autorów wiązali metodę projektów z metodą kompleksów stosowaną w Związku Radzieckim ${ }^{16}$.

Jednak samo wzmiankowanie o metodzie projektów, nawet jeśli nie nosiło piętna ideologicznego, nie mogło sprawić, aby właśnie ta forma praca zagościła w polskiej szkole okresu PRL-u. Szkoła ta była bowiem w swoich założeniach daleka od idei przyświecających realizacji projektów: wyzwoleniu twórczej aktywności uczniów, ich autonomii, odpowiedzialności czy środowiskowej aktywności.

Po roku 1989 metoda projektów zaczęła w polskich szkołach zyskiwać na popularności, choć nie nastąpiła bezpośrednio po przełomie społeczno-politycznym. Po dekadach realnego socjalizmu pojawiła się potrzeba i próby zmiany szkoły w miejsce prawdziwie twórczego i autonomicznego rozwoju, współdziałania i aktywności, jednakże procesy przemian w edukacji cechowała niespójność koncepcji i ciągle oscylowanie między destabilizacją a rewolucyjnością, reformowaniem a ewolucyjnościa przemian, zaangażowaniem z kontestacja, demokracją liberalna i plebiscytarna ${ }^{17}$. Dopiero po 10 latach od przełomu 1989 r. przeprowadzono radykalną reformę edukacji, która spowodowała pewne wzmożenie zainteresowania metodami aktywizującymi. Ukazało się wtedy sporo prac przybliżających metodę projektów polskim pedagogom ${ }^{18}$. Zwracano uwagę na takie jej cechy, jak progresywistyczna rola nauczyciela, podmiotowość ucznia czy związek z szerszym środowiskiem społecznym ${ }^{19}$. Omawiając w publikacjach metodę projektów, sięgano do myśli W. Kilpatricka, uwypuklając główne założenia amerykańskiego myśliciela: prymat samodzielnego zdobywania wiedzy, w sytuacjach które są związane z życiem dzieci i młodzieży, decyzyjność uczniów, uwzględnianie w pracy edukacyjnej naturalnych predyspozycji wychowanków czy znaczenie motywacji w działaniu projektowym ${ }^{20}$.

Pomimo wielu prac dostarczających teoretycznej podbudowy do realizacji projektów, trudno było w owym czasie uznać, aby metoda projektów zaczęła być powszechnie stosowana w edukacji formalnej. Jej obecność w szkołach w dużej mierze zależała od inicjatywy indywidualnych nauczycieli, którzy znajdowali wsparcie wśród organizacji pozarządowych wnoszących niemały wkład w upowszechnienie tego sposobu pracy, proponując projekty tematyczne, oferując materiały edukacyjne i szkolenia dla nauczycieli i młodzieży.

15 B. Nawroczyński, op. cit., s. 316-320; K. Sośnicki, op. cit., 206; S. Wołoszyn, op. cit., s. 419.

${ }^{16}$ K. Sośnicki, op. cit., s. 209, J. Miąso J., Historia wychowania. Wiek XX, Warszawa 1984, s. 64.

${ }_{17}$ B. Śliwerski, Manipulacje w polityce oświatowej III RP, w: Nauczyciel w krajach postsocjalistycznych. Studium teoretyczno-empiryczne, red. A. Wróbel, Łódź 2010, s. 39.

18 J. H. Harris, L. G. Katz, Mali badacze. Metoda projektu w edukacji elementarnej, Warszawa 2003; J. Królikowski, Projekt edukacyjny. Materiaty dla zespołów międzyprzedmiotowych, Warszawa 2001; K. Chałas, Metoda projektów i jej egzemplifikacja w praktyce. W poszukiwaniu strategii edukacyjnych zreformowanej szkoty, Warszawa 2000; Szymański, op. cit.; D. Gołębniak, Uczenie metoda projektów, Warszawa 2002.

19 M. Szymański, op. cit., s. 66-67.

${ }^{20}$ Ibidem, s. 31. 


\section{Nowa podstawa programowa $\mathrm{z}$ metodą projektów}

Wzmożone zainteresowanie metodą projektów pojawiło się w polskiej oświacie w czasie opracowywania nowej podstawy programowej kształcenia ogólnego w roku 2008. Zwrócono w niej uwagę na konieczność kształcenia młodego pokolenia w kierunku obywatelskości, zaangażowania w sprawy społeczne i współpracy, do których to celów metoda projektów wydawała się idealnie przystosowana. Źródła inspiracji dla takiego podejścia mogą być rozmaite, ale wydaje się, że jednym z nich były alarmujące wyniki dotyczące poziomu kapitału społecznego polskiego społeczeństwa, którego charakterystyki dostarcza regularnie badanie pod nazwą Diagnoza Społeczna ${ }^{21}$. Kapitał społeczny uznawany jest za niezbędny warunek sprawnie funkcjonującego społeczeństwa obywatelskiego, opartego na zdrowych relacjach społecznych, dbaniu o dobro wspólne $i$ współpracy, a rezultaty badania jednoznacznie pokazały brak umiejętności współpracy i niski poziom zaufania Polaków ${ }^{22}$. Poza Diagnoza Społeczna, jedną z inspiracji do zmiany podstawy programowej w kierunku ,prospołecznym” były także opracowane przez Parlament Europejski i Radę kompetencje kluczowe, wśród których wymieniono „przedsiębiorczość i innowacyjność”, czyli zdolność praktycznej realizacji pomysłów, co wymaga kreatywności, innowacyjności, podejmowania ryzyka, umiejętności planowania i zarządzania ${ }^{23}$. Ponadto, Jacek Strzemieczny wskazuje na takie źródła upowszechnienia projektów, jak rządowa strategia Polska 2030 oraz Strategia Rozwoju Kapitału Społecznego opracowana przez Ministerstwo Kultury i Dziedzictwa Narodowego ${ }^{24}$.

W nowej podstawie programowej kompetencje kluczowe zostały ujęte m.in. w celach kształcenia ogólnego odnoszących się do zdobywania przez uczniów umiejętności wykorzystania wiadomości podczas wykonywania zadań i rozwiązywania problemów oraz kształtowania u uczniów postaw warunkujacych sprawne i odpowiedzialne funkcjonowanie we współczesnym świecie ${ }^{25}$. Jak wspomniano, nowa podstawa programowa została wprowadzona w 2008 r., a przedmiotem kształtującym pożądane postawy miał być przede wszystkim przedmiot Wiedza o społeczeństwie. W nowej podstawie programowo-

\footnotetext{
${ }^{21}$ Diagnoza Społeczna jest naukowym projektem interdyscyplinarnym, którego celem jest kompleksowa analiza warunków i jakości życia Polaków. Diagnoza obejmuje aspekty ekonomiczne i pozaekonomiczne, w tym dobrostan psychiczny, zaangażowanie obywatelskie, styl życia. Badanie przeprowadzane jest cyklicznie, co dwa lata (od 2000 r.) i ma charakter panelowy - badacze wracają do tych samych gospodarstw i osób, o jednakowej porze roku (marzec), co wyklucza wpływ efektu sezonowości. Diagnoza dostarcza zatem obrazu nie tylko sytuacji teraźniejszej, ale pozwala śledzić przemiany społeczne na przestrzeni lat, J. Czapiński, Wstęp, w: Diagnoza Społeczna, Warunki i jakość życia Polaków, red. J. Czapiński, T. Panek, Warszawa 2011, s. 13.

22 J. Czapiński, Kapital społeczny, w: Diagnoza Społeczna, Warunki i jakość życia Polaków, red. J. Czapiński, T. Panek, Warszawa 2011, s. 284-293.

${ }^{23}$ Lifelong learning — key competences, http://europa.eu/legislation_summaries/education_training youth/lifelong_learning/c11090_en.htm.

24 J. Strzemieczny, Jak organizować i prowadzić gimnazjalne projekty edukacyjne. Poradnik dla dyrektorów, szkolnych organizatorów i opiekunów projektów, Warszawa 2010;

25 Dziennik Ustaw, Rozporzadzenie Ministra Edukacji Narodowej z dnia 23 grudnia 2008 r. w sprawie podstawy programowej wychowania przedszkolnego oraz kształcenia ogólnego w poszczególnych typach szkót, Dz.U. Nr 4 poz. 17. s. 206).
} 
wej do tego przedmiotu dla gimnazjów jako jeden z celów ogólnych wymienia się Współdziałanie $w$ sprawach publicznych. (Uczeń wspótpracuje z innymi-planuje, dzieli się zadaniami $i$ wywiąuje się z nich ${ }^{26}$. W wymaganiach szczegółowych z kolei znajdujemy punkt dotyczący udziału obywateli w życiu publicznym. Jego realizacja ma być możliwa m.in. dzięki opracowaniu - indywidualnie lub w zespole - projektu uczniowskiego dotyczącego rozwiązania jednego z problemów społeczności szkolnej lub lokalnej i w miarę możliwości zrealizowania go (np. jako wolontariusz) ${ }^{27}$. Dla czwartego etapu edukacyjnego, czyli szkół ponadgimnazjalnych, podstawa programowa w zakresie podstawowym i rozszerzonym rozwija cel ogólny, dodając, że uczeń sprawnie korzysta z procedur i możliwości, jakie stwarzaja obywatelom instytucje życia publicznego; zna i stosuje zasady samoorganizacji i samopomocy ${ }^{28}$ (W dokumencie zwraca się uwagę, że zajęcia z omawianego przedmiotu mają kształtować postawy tolerancji, obywatelskiego zaangażowania, wrażliwości społecznej, odpowiedzialności, winny też wzmacniać poczucie więzi społecznych). Odbiciem postulatów cytowanej już Diagnozy Społecznej jest w podstawie programowej zapis dotyczący konieczności zapewnienia przez szkołę takich warunków, aby uczniowie mogli m.in. brać udział w życiu społeczności lokalnej, nawiązywać kontakty i współpracować z organizacjami społecznymi, uczestniczyć w obywatelskich kampaniach i budować poczucie sprawstwa $w$ życiu społecznym oraz zaufanie do innych ${ }^{29}$. Elementem, który został przewidziany jako „nośnik” w/w treści jest przewidziany nową podstawą programową projekt uczniowski - około $20 \%$ treści nauczania $\mathrm{w}$ gimnazjach, a 10\% w szkołach ponadgimnazjalnych powinno być realizowanych właśnie przez projekty. Podstawa programowa określa, że realizując go uczeń wybiera problem lub działanie, które będą przedmiotem projektu, poszukuje sposobów zbadania i rozwiązania problemu lub przeprowadzenia działania, realizuje w sposób przemyślany i konsekwentny zaplanowane przesięwzięcia, jest organizatorem własnej pracy, jednocześnie współpracując z innymi członkami zespołu, a na końcu przeprowadza publiczną prezentację projektu ${ }^{30}$. Podstawą prawną, dzięki której realnie wprowadzono projekty było Rozporzadzenie Ministra Edukacji Narodowej z dnia 20 sierpnia 2010 r. zmieniajace rozporządzenie w sprawie warunków i sposobu oceniania, klasyfikowania i promowania uczniów $i$ stuchaczy oraz przeprowadzania sprawdzianów $i$ egzaminów $w$ szkołach publicznych. W owym dokumencie znajdujemy informację, że projekt jest zespołowym, planowym działaniem uczniów, mającym na celu rozwiązanie konkretnego problemu, $z$ zastosowaniem różnorodnych metod. Rozporządzenie wyszczególnia ponadto etapy

${ }^{26}$ Podstawa programowa z komentarzami. Tom 4. Edukacja historyczna i obywatelska w szkole podstawowej, gimnazjum i liceum. Warszawa 2008, s. 85.

27 Ibidem, s. 86.

28 Ibidem, s. 93.

29 Ibidem, s. 110.

${ }^{30}$ Ibidem, s. 110-111. 
projektu (wybór tematów, określenie celów i etapów, wykonanie działań, publiczne przedstawienie rezultatów) ${ }^{31}$.

Wraz z przywoływanym dokumentem realizacja szkolnych projektów została prawnie usankcjonowana jako pożądana metoda działania, co z pewnością przyczynia się do jej powszechności. Z drugiej strony, istnieje niebezpieczeństwo, iż sformalizowanie obowiązku przeprowadzania projektu spowoduje lub już spowodowało postrzeganie tego typu działań jako jeszcze jednego narzuconego wymogu, który staje się elementem szkolnej rutyny zamiast prawdziwie twórczą edukacyjną przygodą.

\section{Zakończenie}

Metoda projektów, choć obecna w naszym edukacyjnym dyskursie prawie sto lat, stała się formalnie obowiązującą wraz z opracowaniem w roku 2008 nowej podstawy programowej. Jak zauważono powyżej, prawne usankcjonowanie niekoniecznie musi korzystnie odbić się na praktycznej realizacji projektów, w której istotna jest autentyczność i spontaniczność działania. Ponadto, zauważyć należy, że przez wiele dekad omawiana metoda, czy to ze względu na jej nowatorski charakter w latach przedwojennych, czy ideologiczną obcość w czasach przed 1989 r., była obecna jedynie śladowo w polskiej edukacji. Pozostaje pytanie, czy po latach jej praktycznej nieobecności i braku społeczno-kulturowego kontekstu, w którym powstawała, potrafimy ją rzeczywiście realizować, tak aby przyczyniała się do wzrostu kapitału społecznego, czyli do budowania społeczeństwa opartego na współpracy i zaufaniu. W tym kontekście, zarysowana przez mnie pokrótce historia metody projektów w Polsce skłania do refleksji nad koniecznością ciągłego i intensywnego kształcenia i dokształcania nauczycieli w tym obszarze. Innym aktualnym problemem pozostaje, jakie w zmieniającej się rzeczywistości owa metoda zajmie miejsce, szczególnie wobec opracowywanych obecnie nowych podstaw programowych. Bardzo źle by się stało, gdyby, jak to bywało już w przeszłości, znalazła się wśród zbędnych, bo kulturowo nam obcych i społecznie niepotrzebnych pedagogicznych pomysłów.

\section{Bibliografia}

Bastgenówna Z., Metoda projektów, „Ruch Pedagogiczny” R. XVII, 1930, nr 6, s. 268-274.

Bereźnicki F., Hasła „Nowej szkoły” w dydaktyce drugiej Rzeczpospolitej, Toruń 1998.

Chałas K. Metoda projektów i jej egzemplifikacja w praktyce. W poszukiwaniu strategii edukacyjnych zreformowanej szkoty, Warszawa 2000.

\footnotetext{
${ }^{31}$ Rozporządzenie Ministra Edukacji Narodowej z dnia 20 sierpnia 2010 r. zmieniające rozporządzenie w sprawie warunków $i$ sposobu oceniania, klasyfikowania i promowania uczniów $i$ stuchaczy oraz przeprowadzania sprawdzianów i egzaminów w szkołach publicznych, Dz.U. Nr 156 poz. 1046.
} 
Czapiński J., Kapitał społeczny, w: Diagnoza Społeczna, Warunki i jakość życia Polaków, red. J. Czapiński, T. Panek, Warszawa 2011.

Czapiński J., Wstęp, w: Diagnoza Społeczna, Warunki i jakość życia Polaków, red. J. Czapiński, T. Panek, Warszawa 2011.

Dzierzbicka W., Dobrowolski S., Eksperymenty pedagogiczne w Polsce w latach 1900-1939, Wrocław 1963.

Gołębniak D., Uczenie metoda projektów, Warszawa 2002.

H.K. (a), Metoda ,projektów”, „Ruch Pedagogiczny” R. XIV, 1927, nr 5, s. 147-151.

H.K. (b), Metoda ,,projektów”, „Ruch Pedagogiczny”, R. XIV, 1927, nr 4, s. 118-121.

Harris H. J., L.G. Katz, Mali badacze. Metoda projektu w edukacji elementarnej, Warszawa 2003.

Królikowski J., Projekt edukacyjny. Materiaty dla zespołów międzyprzedmiotowych, Warszawa 2001.

Miąso J., Historia wychowania. Wiek XX, Warszawa 1984.

Molak A., Metoda projektów, w: Szkoły eksperymentalne w świecie 1900-1975, red. W. Okoń, Warszawa 1977.

Nawroczyński B., Dzieła wybrane. Zasady nauczania, tom II, Warszawa: WSiP, 1987.

Pieter J., Johna Dewey'a myśli przewodnie o wychowaniu, „Chowanna” R. XIII, 1958, nr 5/6, s. $248-274$.

Podstawa programowa z komentarzami. Tom 4. Edukacja historyczna i obywatelska w szkole podstawowej, gimnazjum i liceum, Warszawa 2008.

Rowid H., Szkoła twórcza, Kraków 1931.

Rozporzadzenie Ministra Edukacji Narodowej z dnia 20 sierpnia 2010 r. zmieniajace rozporzadzenie w sprawie warunków $i$ sposobu oceniania, klasyfikowania i promowania uczniów i sluchaczy oraz przeprowadzania sprawdzianów $i$ egzaminów $w$ szkołach publicznych, Dz.U. $\mathrm{Nr} 156$ poz.1046.

Rozporzadzenie Ministra Edukacji Narodowej z dnia 23 grudnia 2008 r. w sprawie podstawy programowej wychowania przedszkolnego oraz kształcenia ogólnego w poszczególnych typach szkót, Dz.U. Nr 4 poz.17.

Sośnicki K., Dydaktyka ogólna, Wrocław1959.

Stevenson J.A., Metoda projektów w nauczaniu, Lwów-Warszawa 1930.

Strzemieczny J., Jak organizować i prowadzić gimnazjalne projekty edukacyjne. Poradnik dla dyrektorów, szkolnych organizatorów i opiekunów projektów, Warszawa 2010;

Szymański M., O metodzie projektów. Z historii, teorii i praktyki pewnej metody ksztatcenia, Warszawa 2000.

Śliwerski B., Manipulacje w polityce oświatowej III RP, w: Nauczyciel w krajach postsocjalistycznych. Studium teoretyczno-empiryczne, red. A. Wróbel, Łódź 2010.

Wołoszyn S., Dzieje wychowania i myśli pedagogicznej w zarysie, Warszawa 1964. 
